\title{
ANALYSIS OF THE EFFECT OF WORK ENVIRONMENT AND INTRINSIC MOTIVATION ON EMPLOYEES PERFORMANCE SUSHI TEI TUNJUNGAN PLAZA SURABAYA
}

\author{
Bunga Erika Putri ${ }^{1}$, Hermien Tridayanti², Mochammad Arif ${ }^{3}$ \\ Bungaerica2001@gmail.com¹ ${ }^{1}$ hermien.tridayanti@narotama.ac.id², muchamad.arif@narotama.ac.id ${ }^{3}$ \\ Faculty Economics and Business, Narotama University, Surabaya
}

\begin{abstract}
The purpose of this study is to find out and analyze the work environment and intrinsic motivation significantly simultaneously on the performance of Sushi Tei Tunjungan Plaza Surabaya employees. With a population of 85 respondents. This research is quantitative and data collection is through questionnaires and observations. Data analysis used is validity test, reliability test, classic assumption test, multiple linear analysis test. The results showed that the analysis of the influence of the work environment and intrinsic motivation on the performance of employees at Tunjungan Plaza Surabaya Sushi Tei on the results of the t test of the work environment wascalculated as $-4.971<$ Ttable 1.666 and intrinsic motivation of Tcount 13.189> Ttable 1.666. For the results of the F test it is known that Fcount 110,267> Ftable 3.11, it can be concluded that environmental variables and intrinsic motivation have ainfluence simultaneouson employee performance.
\end{abstract}

Keyword: Work environment, Intrinsic Motivation, Employee Performance.

\section{INTRODUCTION}

Human resources are the most important thing for determining company goals. Therefore, human resources need to get serious attention so that they can be managed properly. Management of human resources that must be mature must be started from the beginning because later that will determine the survival of the company. Many restaurants do to improve performance in order to obtain customer satisfaction.

A company often only requires high performance on its employees without looking at the influencing factors. Though the fundamental factors in supporting performance such as work environment and work motivation must be considered also in order to increase employee productivity.

PT. Sushi Tei Surabaya is a company engaged inservices food and beverage that serves Japanese specialties. What happened at Tunjungan Plaza Surabaya Sushi Tei, which is between one leader and another leader, is not in line with the company's vision and mission. The motivation applied in Sushi Tei is to hold training every week in order to improve performance, a competition is held for employees who are able to sell special products to be rewarded in the form of cash, in Sushi Tei tests are held once a month and in three months receive a report exams with values above the average, the company will provide a salary increase in advance of other employees. Often there is a misunderstanding of the instructions given by the leadership which results in a decrease in employee morale that has an impact on a less harmonious work situation, unsatisfactory service to customers, often talking to other employees while working so that customers are often overlooked and cause reprimands and punishments. punishmen that affect the psychological behavior of Sushi tei employees. Supported by the employees of Sushi Tei who were less competent, their performance declined.

\section{THEORY FRAMEWORK}

\section{Work Environment}

According to Sunyoto (2012: 43), the work environment is everything that exists around the workers and that can affect themselves in carrying out tasks that are caused, such as cleanliness, music, lighting and others. Intrinsic Motivation

According to Priyono (2008: 283), intrinsic motivation is the motivation of work that comes from within the worker as an individual, in the form of awareness of the importance or benefits or meaning of the work carried 
out in other words this motivation is the work done, either because meet needs, or menyenngkan, orexpectations allow achieving certain positivein the future.

\section{EmployeePerforme}

According to Hasibuan (2010), employee performance is a result of work achieved by someone in carrying out tasks assigned to him based on skills, experience, and sincerity and time

\section{RESEARCH METHODS}

\section{Population}

Population is a generalization area consisting of: objects or subjects that have certain qualities and characteristics set by researchers to be studied and then drawn conclusions (Sugiyono, 2010).

\section{Types data}

data used in this study are primary data data obtained directly and make their own observations of the

objects under study from Employees of Sushi Tei Tunjungan Plaza Surabaya.

\section{Data source}

Sources The data sources used in this study were questionnaires distributed directly to respondents.

\section{Data Collection Techniques}

a. The data explaining technique in this study is using questionnaires, namely a method of collecting data in which the researcher compiles a list of questions in writing and then distributes them to respondents to obtain data needed by researchers and collect data from library studies obtained from books, journals and other sources.

b. The data collection technique in this study is to use observations by conducting direct observations on the activities of Sushi Tei Tunjungan Plaza Surabaya employees.

\section{Conceptual Framework of Research}

Figure 1 Conceptual Framework for Research

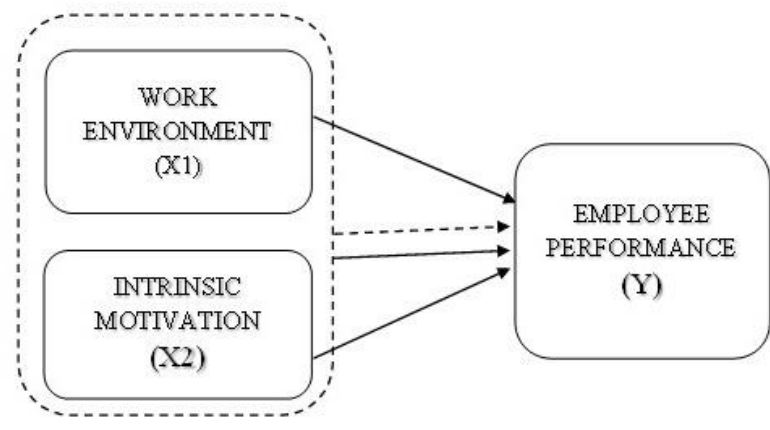

Partially

Simultaneously

Sumber: Data primer diolah 2019

\section{Methods Validity and Reliability Tests}

According to Priyatno (2010: 90), the validity test is explained as the accuracy or speed of an instrument in measuring what it wants to measure. According to Umar (2008: 56), the reliability test for alternative jabawan is better using Cronbach's alpha, whose value will be compared with the acceptable minimum reliability coefficient value. Reliability of less than 0.6 is not good, while 0.7 is acceptable, and more than 0.8 is good

\section{Multiple Regression Analysis}

According to Sugiyono's explanation (2006: 210), the analysis is conducted to find out whether in the regression analysis model there is a simultaneous influence between independent variables (independent) with the dependent variable (dependent). The regression equation in this study can be formulated as follows:

Multiple linear regression models are used:

$\mathrm{Y}=\mathrm{a}+\mathrm{b} 1 \mathrm{X} 1+\mathrm{b} 2 \mathrm{X} 2+\ldots \mathrm{bnX} 1+\mathrm{e}$

Where:

Y: employee performance level 
A: constant

b1, b2: coefficient correlation

$\mathrm{X} 1$ : Work environment variable dimensi score

$\mathrm{X} 2$ : Dimension score of intrinsic motivation variable.

E: error estimet

\section{RESULTS AND DISCUSSION}

\section{Reliability and validity}

Based on research shows that the cronbanch alpha value of work environment is 0.723 , intrinsic motivation is 0.712 , and employee performance is 0.765 , which means that it is above the acceptance limit of 0.6 . Based on the research value of the correlation index for the relationship between the independent variable (work environment and intrinsic motivation) and the dependent variable (employee performance) greater than 0.213 from the $r$ table and below the significant level of 0.05 , the results of the validity test of all the items show results positive, therefore, the data is considered valid.

\section{The results of multiple linear regression}

Table 1: Results multiple linear regression analysis

Coefficient ${ }^{\mathrm{a}}$

\begin{tabular}{|c|c|c|c|c|c|c|c|}
\hline \multirow[t]{2}{*}{ Model } & $\begin{array}{c}\text { Unstandardzid } \\
\text { e Coefficient }\end{array}$ & & $\begin{array}{l}\text { Standartdize } \\
\text { d Coefficients }\end{array}$ & \multirow[t]{2}{*}{$\mathbf{T}$} & \multirow[t]{2}{*}{ Sig. } & $\begin{array}{l}\text { Collineart } \\
\text { y Statistics }\end{array}$ & \\
\hline & B & $\begin{array}{l}\text { Std. } \\
\text { Error }\end{array}$ & Beta & & & Tolerance & VIF \\
\hline \multirow{3}{*}{$\begin{array}{l}\text { (Constant) } \\
\text { Work_environment } \\
(\mathrm{X} 1) \\
\text { Intrinsic_motivation } \\
\text { (X2) }\end{array}$} & 5.420 & 1.396 & & 3.882 & .000 & & \\
\hline & -.431 & .087 & -.418 & $\begin{array}{c}- \\
4.971\end{array}$ & .000 & .466 & 2.144 \\
\hline & 1.168 & .089 & 1.110 & $\begin{array}{c}13.18 \\
9\end{array}$ & .000 & .466 & 2.144 \\
\hline
\end{tabular}

Source: Primary data processed with SPSS, 2019

From the above equation has the same as follows:

a. The constant $(\alpha)$ of 5.420 shows that if there is an influence of the independent variable (X1, X2) in the

b. form of a work environment variable, intrinsic motivation, the employee's performance will remain 5.420

c. The working environment regression coefficient (b1) is negative at -0.431 , this means that if the work environment decreases by one unit then the performance will decrease by 0.431 .

d. Intrinsic motivation regression coefficient (b2) is positive for 1168, this means that if the work environment increases one unit will increase the performance of units of 1,168

\section{Results From R Square}

Table 2:coefficient of determination

\begin{tabular}{|c|c|c|c|c|}
\hline \multicolumn{5}{|c|}{ Model Summary $^{\mathbf{b}}$} \\
\hline Model & $\mathrm{R}$ & R Square & Adjusted R Square & $\begin{array}{c}\text { Std. Error of the } \\
\text { Estimate }\end{array}$ \\
\hline 1 & $.854^{\mathrm{a}}$ & .729 & .722 & 1.24962 \\
\hline
\end{tabular}

a. Predictors: (Constant), Work_environment, Intrinsic_motivation

b. Dependent Variable: employee_performance

Source: Primary data processed with SPSS, 2019

From the coefficient of determination can be seen from the influence of the work environment, intrinsic motivation has an effect simultaneously on employee performance with an Adjusted R Square value of 0.722. This means that in this study $72.9 \%$ of the performance of Sushti Tei Tunjungan Plaza Surabaya employees was influenced by the work environment and intrinsic motivation. $27.1 \%$ is influenced by other variables not examined by the researcher. 


\section{Classical Assumption Test}

The Results of Multicollinearity

Table 3: multicolinerity test

\begin{tabular}{|c|c|c|c|}
\hline \multicolumn{4}{|c|}{ Coefficients $^{\mathrm{a}}$} \\
\hline \multirow{2}{*}{\multicolumn{2}{|c|}{ Model }} & \multicolumn{2}{|c|}{ Collinearity Statistics } \\
\hline & & Tolerance & VIF \\
\hline \multirow[t]{3}{*}{1} & (Constant) & & \\
\hline & $\begin{array}{l}\text { Work_environment } \\
\text { (X1) }\end{array}$ & .466 & 2.144 \\
\hline & $\begin{array}{l}\text { Intrinsic_motivatio } \\
\mathrm{n}(\mathrm{X} 2)\end{array}$ & .466 & 2.144 \\
\hline
\end{tabular}

Source: Primary data processed with SPSS, 2019

The results of the multicollinearity test show that the work environment variable (X1) has a tolerance value of less than 1 and has a VIF value of $2.144<10$, in the intrinsic motivation variable (X2) the tolerance value is less than 1 and has a VIP value of $2.144<10$.

\section{Heterokedasticity and Test Glejser}

\section{Tabel 4: Heteroscedasticity test}

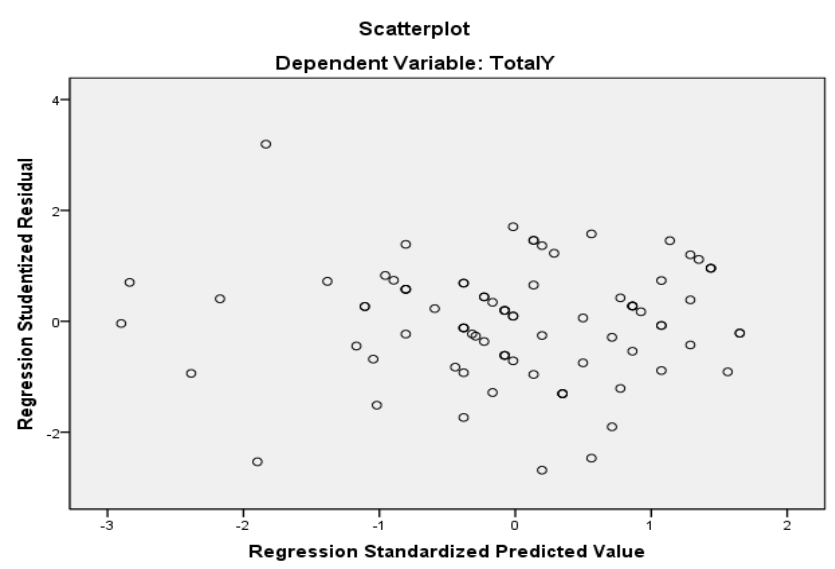

Source: Primary data processed with SPSS, 2019

The conclusion of these results is that there is no problem of heteroscedasticity. For more accurate results the researchers used the glejser test as a support for the above results, as follows:

\section{Tabel 5: test glejser}

Coefficients $^{\mathbf{a}}$

\begin{tabular}{|ll|l|l|l|l|l|}
\hline \multirow{2}{*}{ Model } & \multicolumn{2}{|l|}{$\begin{array}{l}\text { Unstandardized } \\
\text { Coefficients }\end{array}$} & \multicolumn{2}{l|}{$\begin{array}{l}\text { Standardized } \\
\text { Coefficients }\end{array}$} & & \\
\cline { 3 - 5 } & & $\mathrm{B}$ & Std. Error & Beta & $\mathrm{T}$ & Sig. \\
\hline 1 & (Constant) & 2.520 & .863 & & 2.919 & .005 \\
& Work_environment(X1) & -.102 & .054 & -.299 & -1.903 & .061 \\
& Intrinsic_motivation(X2) & .031 & .055 & .088 & .561 & .576 \\
\hline
\end{tabular}


Coefficients $^{\mathrm{a}}$

\begin{tabular}{|ll|l|l|l|l|l|}
\hline \multirow{2}{*}{ Model } & \multicolumn{2}{l|}{$\begin{array}{l}\text { Unstandardized } \\
\text { Coefficients }\end{array}$} & \multicolumn{2}{l|}{$\begin{array}{l}\text { Standardized } \\
\text { Coefficients }\end{array}$} & & \\
\cline { 3 - 5 } & & $\mathrm{B}$ & Std. Error & Beta & T & Sig. \\
\hline 1 & (Constant) & 2.520 & .863 & & 2.919 & .005 \\
& Work_environment(X1) & -.102 & .054 & -.299 & -1.903 & .061 \\
& Intrinsic_motivation(X2) & .031 & .055 & .088 & .561 & .576 \\
\hline
\end{tabular}

a. Dependent Variable: abs_res

Source: Primary data processed with SPSS, 2019

In the glejser test it was said that there was no problem with heterocedasticity if the sig value was present. greater than 0.05 . Based on these results indicate that the significant value of the work environment variable (X1) is $0.061>0.05$. In the intrinsic motivation variable $(\mathrm{X} 2)$ the sig value. $0.576>0.05$. It can be concluded that the significant value on each variable shows greater than 0.05 can be interpreted that there is no heterocedasticity problem

Tabel 6:Test normal distribution

\begin{tabular}{|c|c|c|}
\hline & & Unstandardized Residual \\
\hline $\mathrm{N}$ & & 85 \\
\hline \multirow{2}{*}{ Normal Parameters ${ }^{\mathrm{a}, \mathrm{b}}$} & Mean & .0000000 \\
\hline & Std. Deviation & 1.23465735 \\
\hline \multirow[t]{3}{*}{ Most Extreme Differences } & Absolute & .068 \\
\hline & Positive & .055 \\
\hline & Negative & -.068 \\
\hline Kolmogorov-Smirnov Z & & .631 \\
\hline Asymp. Sig. (2-tailed) & & .820 \\
\hline
\end{tabular}

a. Test distribution is Normal.

b. Calculated from data.

Source: Primary data processed with SPSS, 2019

Tabel 7:Test normal distribution

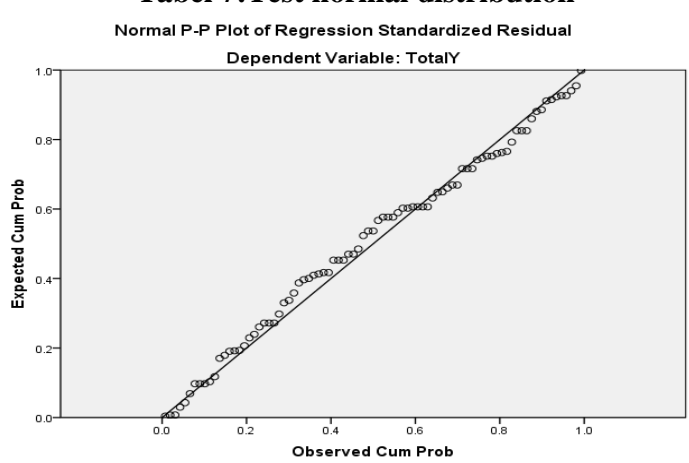

Based on the results of the normality test above, it is known that the value of significant is $0.820>0.05$ so it can be interpreted if the research data is normally distributed.

Test $\mathbf{t}$

Table 8: T-test results

Coefficients $^{\mathrm{a}}$

\begin{tabular}{|c|c|c|c|c|c|c|c|}
\hline \multirow{2}{*}{ Model } & \multicolumn{2}{|c|}{$\begin{array}{c}\text { Unstandardized } \\
\text { Coefficients }\end{array}$} & \multirow{2}{*}{$\begin{array}{c}\text { Standardized } \\
\text { Coefficients }\end{array}$} & \multirow{2}{*}{$\mathbf{T}$} & \multirow{2}{*}{ Sig. } & \multicolumn{2}{|c|}{ Collinearity Statistics } \\
\hline & B & $\begin{array}{l}\text { Std. } \\
\text { Error }\end{array}$ & & & & Tolerance & VIF \\
\hline $\begin{array}{ll}1 & \text { (Constant) } \\
& \text { Work_environment }(\mathrm{X} 1) \\
& \text { Intrinsic_motivation(X2) }\end{array}$ & $\begin{array}{l}5.420 \\
-.431 \\
1.168\end{array}$ & $\begin{array}{l}1.396 \\
.087 \\
.089\end{array}$ & $\begin{array}{l}-.418 \\
1.110\end{array}$ & $\begin{array}{l}3.882 \\
-4.971 \\
13.189\end{array}$ & $\begin{array}{l}.000 \\
.000 \\
.000\end{array}$ & $\begin{array}{l}.466 \\
.466\end{array}$ & $\begin{array}{l}2.144 \\
2.144\end{array}$ \\
\hline
\end{tabular}




\begin{tabular}{|c|c|c|c|c|c|c|c|}
\hline \multicolumn{8}{|l|}{ Coefficients $^{\mathbf{a}}$} \\
\hline \multirow[b]{2}{*}{ Model } & \multicolumn{2}{|c|}{$\begin{array}{c}\text { Unstandardized } \\
\text { Coefficients }\end{array}$} & \multirow{2}{*}{$\begin{array}{c}\begin{array}{c}\text { Standardized } \\
\text { Coefficients }\end{array} \\
\text { Beta } \\
\end{array}$} & \multirow[b]{2}{*}{$\mathbf{T}$} & \multirow{2}{*}{ Sig. } & \multicolumn{2}{|c|}{ Collinearity Statistics } \\
\hline & B & $\begin{array}{c}\text { Std. } \\
\text { Error }\end{array}$ & & & & Tolerance & VIF \\
\hline $\begin{array}{ll}1 & \text { (Constant) } \\
& \text { Work_environment(X1) } \\
& \text { Intrinsic_motivation(X2) }\end{array}$ & $\begin{array}{l}5.420 \\
-.431 \\
1.168 \\
\end{array}$ & $\begin{array}{l}1.396 \\
.087 \\
.089\end{array}$ & $\begin{array}{l}-.418 \\
1.110\end{array}$ & $\begin{array}{l}3.882 \\
-4.971 \\
13.189\end{array}$ & $\begin{array}{l}.000 \\
.000 \\
.000\end{array}$ & $\begin{array}{l}.466 \\
.466\end{array}$ & $\begin{array}{l}2.144 \\
2.144\end{array}$ \\
\hline
\end{tabular}

a. Dependent Variable: totally

Source: Primary data processed with SPSS, 2019

To interpret the results of the hypothesis from the analysis, it can be explained as follows:

a. The value of $\mathrm{T}_{\text {count }}$ is $-4.971<\mathrm{T} 1.666$ table. So that it can be concluded that Ho is accepted and Ha is rejected means there is no significant negative effect $\mathrm{X}_{1}$ on $\mathrm{Y}$.

b. The value of Tcounts 13,189> Ttable 1,666. So it can be concluded that Ho is rejected and Ha is accepted, meaning there is a significant positive effect of $\mathrm{X}_{2}$ on $\mathrm{Y}$.

Test F

\begin{tabular}{|c|c|c|c|c|c|}
\hline \multicolumn{6}{|c|}{$\begin{array}{c}\text { Table 9: Test } \mathbf{F} \\
\text { ANOVA }^{\mathbf{b}}\end{array}$} \\
\hline Model & Sum of Squares & Df & Mean Square & $\mathbf{F}$ & Sig. \\
\hline $\begin{array}{ll}1 & \text { Regression } \\
& \text { Residual } \\
& \text { Total } \\
\end{array}$ & $\begin{array}{l}344.376 \\
128.048 \\
472.424 \\
\end{array}$ & $\begin{array}{l}2 \\
82 \\
84 \\
\end{array}$ & $\begin{array}{l}172.188 \\
1.562\end{array}$ & 110.267 & $.000^{\mathrm{a}}$ \\
\hline
\end{tabular}

a. Predictors: (Constant), Intrinsic_motivation(X2), Work_environment(X1

b. Dependent Variable: totally

Source: Primary data processed with SPSS, 2019

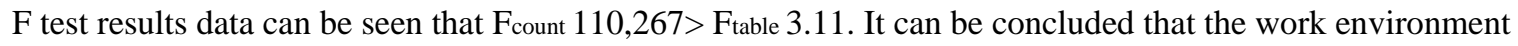
(X1), intrinsic motivation (X2) has a simultaneous influence on employee performance (Y).

\section{Discussion}

\section{The Effect of the Work Environment on Employee Performance}

Based on the results of the first hypothesis test, the results show that the work environment has an effect on the performance of Tunjungan Plaza Surabaya Sushi Tei employees, partially this has been proven by t-test of Tcount -4.971 <Ttable 1,666 can be said that Ho is accepted and Ha is rejected which has no significant negative effect X1 on Y. This can be explained that the decreasing level of work environment will decrease the performance of employees. The work environment is very important in improving employee performance.

The insignificant effect of the work environment on employee performance was also obtained from the results of multiple linear regression analysis. Multiple linear regression analysis of the work environment indicates a negative increase of -0.431 , this means that if the work environment decreases by one unit then the performance will decrease by 0.431 . The condition of sushi tei tunjungan plaza surabaya when observing the results if the relationship between employees and the leadership will help in the work, the level of the work environment will increase but if the help from the leadership makes the employee's performance decreases. This was also evidenced by the statement of the questionnaire stating that the relationship between the employees and the leadership helped in the work, dominant sushi staff from Tunjungan Plaza Surabaya chose to agree enough to the statement. With the help of a leader making sushi tei tunjungan plaza employees feel light on the job but employees tend to feel there will always be assistance from the leadership.

Previous research results of Agung Dwi (2013), which states that the work environment does not affect employee performance. The work environment has no (not significant) influence on the performance of the teaching staff of the district's extraordinary education foundation Demak. Research Dwilaksono (2017), which states that the work environment on employee performance does not have a significant effect, it can be concluded that the work environment variable according to respondents at PT BNI Life Insurance division of employee benefits does not affect performance. 


\section{Effect of Intrinsic Motivation on Employee Performance}

Based on the results of the first hypothesis test, the results obtained that intrinsic motivation affects the performance of employees of PT. Tunjungan Plaza Surabaya Sushi Tei, partially this has been proven by t test the value of Tcount 13,189> Ttable 1,666 can be said that Ho is rejected and Ha is accepted which has significant positive effect X2 on Y. This can be explained that the higher the level of intrinsic motivation then increasing employee performance. Intrinsic motivation plays an important role in improving employee performance.

The significant influence of intrinsic motivation on employee performance was also obtained fromthe results of multiple linear regression analysis. Multiple regression analysis of intrinsic motivation indicates a positive value of 1.110 , this means that if intrinsic motivation increases one unit of food will increase the performance by 1.110 . The greater the intrinsic motivation, the better the performance of employees who are hailed.

\section{The Effect of the Work Environment and Intrinsic Motivation on Employee Performance}

Based on the hypothesis test, the results show that the work environment and intrinsic motivation have a significant effect on performance. Based on the F test, it can be seen that the work environment and intrinsic motivation together have a positive and significant effect on employee performance. Can be seen from the results of the $\mathrm{F}$ test is known that $\mathrm{F}_{\text {count }} 110,267>$ Ftable 3.11, which means that the greater the level of work environment and intrinsic motivation simultaneously, the better the performance of employees will be generated.

\section{CONCLUTION AND SUGGESTION}

\section{Conclution}

This study aims to see the effect of the work environment and intrinsic motivation on the performance of employees of PT. Sushi Tei Tunjungan Plaza Surabaya. Based on the description of the results in the previous chapter, some conclusions can be drawn as follows:

1. Based on the results of testing the first hypothesis, it is known that work environment variables have a significant effect on employee performance with negative direction. The lower the level of work environment that employees have, the lower the level of employee performance.

2. Based on the results of testing the second hypothesis it is known that the intrinsic motivation variable has a significant effect on employee performance in a positive direction. The higher the level of intrinsic motivation employees have, the higher the level of employee performance.

3. Based on the results of the $\mathrm{f}$ test it can be seen that the work environment and intrinsic motivation have a simultaneous influence on employee performance. So the higher the level of work environment and the intrinsic motivation together that employees have, the higher the level of employee performance.

\section{Suggetions}

From the conclusions described above, the researcher gives several suggestions as follows:

1. Suggestions for the next researcher. This research is expected to be used as a reference and information for future researchers. For further research, it can expand the research not only in the branch but all of Sushi Tei Surabaya. For further research you can try using free vairabel in addition to the work environment and intrinsic motivation.

2. Suggestions for Sushi Tei Tunjungan Plaza Surabaya. It is expected that Tunjungan Plaza Surabaya Sushi Tei will pay attention to the work environment and intrinsic motivation because the existence of a work environment and intrinsic motivation that supports employee performance will support productivity by itself.

3. It is best to do by Tunjungan Plaza Surabaya Sushi Tei, which is to increase the work environment and intrinsic motivation through brefing every day so thatperformance employeecan increase.

\section{REFFERENCE}

Atmadja, A. W. T., Novianti, N. K., Yuniarta, G. A. (2014). Pengaruh Independensi, Motivasi, Pengalaman Intrinsik dan Keahlian Profesional Badan Pengawas Terhadap Efektivitas Penerapan Pengendalian Intern Lembaga Perkreditan Desa (LPD) di Kecamatan Kuta Selatan Kabupaten Badung. Jurnal Akuntansi Universitas 
Pendidikan Ganesha. 2(1).

Danang Sunyoto. (2012). Teori, Kuesioner, dan Analisis Data Sumber Daya Manusia. Yogyakarta:STIE, YKPN

DR. surya dharma, mpa. (2003). manajemen kinerja.

Ghazali, I. (2009). Aplikasi Analisis Mutivariete dengan Program SPSS (Universita). Semarang.

Hasibuan, M. (2010). Organisasi dan Motivasi (Cetakan Ke). jakarta.

I Made Yusa Dharmawan. (n.d.). Pengaruh Kompensasi Dan Lingkungan Kerja Non Fisik Terhadap Disiplin Dan

Kinerja Karyawan Hotel Nikki Denpasar. Program Studi Manajemen Program Pascasarjana, Universitas

Udayana.

Mathis, R. L. dan J. H. J. (2006). Human Resource Management, terjemahan (Edisi Kese). Jakarta, Salemba Empat.

Priyatno, D. (2010). Paham Analisis Statistik Data Dengan SPSS (Cetakan Pe). yogyakarta : Media Kom.

Prof. Dr.Wilson bangun,S.E., M. S. (2012). manajemen sumber daya manusia.

priyono marnis. (2008). Manajemen sumber daya manusia (teddy chandra, ed.). zifatama publisher.

Sugiyono. (n.d.). Metode Penelitian, Kualitatif, Dan R\&D. (cetakan ke; Alfabeta, ed.). Bandung.

Umar, H. (2008a). Desain Penelitian MSDM dan Perilaku karyawan: Paradigma Positivistik dan Berbasis

Pemecahan Masalah (Edisi 1, C). Jakarta : Raja Grafindo Persada.

Umar, H. (2008b). Desain Penelitian MSDM dan Perilaku Karyawan: Paradigma Positivistik dan Berbasis

Pemecahan Masalah (Edisi 1, C). Jakarta : Raja Grafindo Persada. 